Hydrol. Earth Syst. Sci., 17, 325-339, 2013

www.hydrol-earth-syst-sci.net/17/325/2013/

doi:10.5194/hess-17-325-2013

(C) Author(s) 2013. CC Attribution 3.0 License.

\title{
How will climate change modify river flow regimes in Europe?
}

\author{
C. Schneider ${ }^{1}$, C. L. R. Laizé ${ }^{2}$, M. C. Acreman ${ }^{2}$, and M. Flörke ${ }^{1}$ \\ ${ }^{1}$ Center for Environmental Systems Research, University of Kassel, Wilhelmshöher Allee 47, 34117 Kassel, Germany \\ ${ }^{2}$ Centre for Ecology and Hydrology, Wallingford, Maclean Building, Crowmarsh Gifford, OX10 8BB, UK \\ Correspondence to: C. Schneider (schneider@usf.uni-kassel.de)
}

Received: 13 July 2012 - Published in Hydrol. Earth Syst. Sci. Discuss.: 3 August 2012

Revised: 22 November 2012 - Accepted: 22 December 2012 - Published: 28 January 2013

\begin{abstract}
Worldwide, flow regimes are being modified by various anthropogenic impacts and climate change induces an additional risk. Rising temperatures, declining snow cover and changing precipitation patterns will interact differently at different locations. Consequently, in distinct climate zones, unequal consequences can be expected in matters of water stress, flood risk, water quality, and food security. In particular, river ecosystems and their vital ecosystem services will be compromised as their species richness and composition have evolved over long time under natural flow conditions. This study aims at evaluating the exclusive impacts of climate change on river flow regimes in Europe. Various flow characteristics are taken into consideration and diverse dynamics are identified for each distinct climate zone in Europe. In order to simulate present-day natural flow regimes and future flow regimes under climate change, the global hydrology model WaterGAP3 is applied. All calculations for current and future conditions (2050s) are carried out on a $5^{\prime} \times 5^{\prime}$ European grid. To address uncertainty, bias-corrected climate forcing data of three different global climate models are used to drive WaterGAP3. Finally, the hydrological alterations of different flow characteristics are quantified by the Indicators of Hydrological Alteration approach. Results of our analysis indicate that on the European scale, climate change can be expected to modify flow regimes remarkably. This is especially the case in the Mediterranean (due to drier conditions with reduced precipitation across the year) and in the boreal climate zone (due to reduced snowmelt, increased precipitation, and strong temperature rises). In the temperate climate zone, impacts increase from oceanic to continental. Regarding single flow characteristics, strongest impacts on timing were found for the boreal climate zone. This applies for both high and low flows. Flow magnitudes, in turn, will be predominantly altered in the Mediterranean but also in the
\end{abstract}

Northern climates. At the end of this study, typical future flow regimes under climate change are illustrated for each climate zone.

\section{Introduction}

In the last century, natural flow regimes have been heavily modified by different anthropogenic impacts (Malmqvist and Rundle, 2002). Worldwide around 50000 large dams and an estimated number of 800000 smaller dams exist, usually generating a less variable flow with elevated low flows and dampened flood peaks (Nilsson et al., 2005). Water demands of an exponential growing world population leads to reduced river discharge due to withdrawals for irrigation, electricity production, manufacturing, domestic purposes and others. In addition, population growth and society's increasing demands on resources have caused immense land-use changes. Urbanization and deforestation result in large sealed areas that alter flow magnitudes and timing through lower evapotranspiration rates and faster runoff (Sahin and Hall, 1996). Many rivers have also been artificially modified by construction works such as channelization, embanking, straightening, widening or deepening with further impacts on flow and flow velocity.

In the future, climate change constitutes another factor for flow regime alteration and will interact with other anthropogenic flow modifications. Climate change "is now evident from observations of increases in global average air and ocean temperatures, widespread melting of snow and ice and rising global average sea level" (IPCC, 2007). Higher temperatures could potentially increase evaporation rates at surfaces and transpiration by plants, which leads to a reduction in runoff (Frederick and Major, 1997). Additionally, in snow 
or glacier-affected river basins, runoff is altered by a decline in meltwater (Verzano and Menzel, 2009). Regionally and seasonally differing developments are simulated for precipitation amounts and patterns (IPCC, 2007) which will cause, depending on the location and season, higher or lower runoff values in the future (Alcamo et al., 2007). Moreover, it is expected that climate change will accelerate the hydrological cycle with an increasing intensity of rainfalls and frequency of extreme weather events (Milly et al., 2008). All these implications will interact in different ways at different climatic locations inducing substantial alterations in the river flow regimes with large geographical disparities in directions and causes.

The consequences of these alterations are manifold. In 2000, approximately 2.4 billion people lived in waterstressed river basins and this number is supposed to rise in the future (Arnell et al., 2011). An increase in water stress can be caused by a reduction in total flow amounts or just by changes in flow seasonality. For example, irrigated agriculture, the largest blue water user worldwide (Rost et al., 2008), depends on the available water resources in the summer season during times of low flows. Even though some basins may attain higher annual runoff values under climate change, the surplus of water is likely occurring during high flow seasons, which will not solve dry season problems (Arnell, 2004; Arnell et al., 2011). Another issue is that higher runoff values in the wet season can enhance the risk of flooding (IPCC, 2007). Next to water quantity issues, water quality is also fundamentally linked to the flow regime as described by Nilsson and Renöfält (2008), especially when rivers are impaired by sewage water or non-point source pollution. Here, flow regime modifications influence transport and concentration of chemicals, nutrients, salts, oxygen and organic matter, but also water temperature which can be crucial for the cooling of thermal power plants (Flörke, 2012a). Furthermore, the shape of rivers can be altered as build-up of sediments and erosion processes change.

Next to economic and social impacts, especially river ecosystems will be at risk due to altered flow regimes. In a river ecosystem, different flows have different ecological functions (Bunn and Arthington, 2000) and can be characterised by their magnitude, timing, duration, frequency, and their rate of change. Poff et al. (1997) describes the ecological functions of these parameters in detail, providing numerous examples from the scientific literature. All in all, the various combinations of flow magnitude, timing, duration, frequency and rate of change shape different habitat features and hence, are important to support a high regional diversity (Allan et al., 2005). Scientists now understand that the total flow regime varying from hydrological droughts to floods is required to maintain biotic composition, integrity, and evolutionary potential of riverine ecosystems including associated floodplains and wetlands (Matthews and Richter, 2007; Richter et al., 1996). Another fundamental assumption of environmental flow research is the natural flow paradigm, which states that the natural flow regime, including natural fluctuations, provides the optimum conditions for a river ecosystem (Poff et al., 1997). Over evolutionary time spans and in direct response to the natural flow regime, native biota has developed different morphological, physiological and behavioural traits as described by Lytle and Poff (2004). Provided habitats are exploited, all ecological niches are occupied and the natural range of flows can be tolerated by the endemic biota. Thus, increasing deviations from natural flow patterns lead to increasing ecological consequences favouring invasive species at the expense of adapted endemic species. Indeed, in a review of 165 papers, Poff and Zimmermann (2010) could clearly demonstrate that flow alteration leads to many ecological consequences. In $92 \%$ of the case studies, impacts on river ecosystems were reported in response to modifications of certain flow parameters. Similar results were found by a review of Lloyd et al. (2004), where $86 \%$ of 65 case studies recorded ecological changes.

Besides possible financial losses in the industrial sector, crop shortfalls and flood damages, the social costs of ecosystem damage will be high as well. Healthy rivers supply a large number of ecosystem services and goods to humanity. Their value has been estimated at $\$ 6.5$ trillion USD globally (Costanza et al., 1997; Strayer and Dudgeon, 2010) and includes water purification, food production, raw material provision, flood mitigation, recreational values and genetic resources to name only a few of them. These vital functions are based on a rich biodiversity and species which are adapted to dynamic conditions of running waters variable in space and time (Giller and Malmqvist, 1998). However, on a global scale, approximately $65 \%$ of all riverine habitats are under severe threat nowadays (Vörösmarty et al., 2010) and the loss of biodiversity has proceeded faster over the last $30 \mathrm{yr}$ than in marine or terrestrial ecosystems (Jenkins, 2003) with loss rates comparable to historical events of great extinctions (Brown and Lomolino, 1998; Ricciardi and Rasmussen, 1999). Indicating changes of fish, bird, reptile, amphibian and mammal populations, the global freshwater living planet index declined by $37 \%$ since 1970 (Grooten et al., 2012). These numbers are alarming and therefore the EU Water Framework Directive (200/60/EEC) demands its Member States to protect and restore water bodies in Europe, aiming for a "Good Ecological Status" for most rivers.

Despite the various impacts on river flow, today only a tiny number of rivers are protected by any sort of environmental flow management (Richter et al., 2012) and according to current trends in riverine species loss, global warming, population growth and land-use change, freshwater ecosystems will remain threatened well into the future (Vörösmarty et al., 2010). Now there is strong consensus within the scientific community that natural flow regimes need to be protected to some degree and that further research on anthropogenic flow regime alteration is required (Richter, 2009; Zang et al., 2012). 
In various studies of the scientific literature, the impact of climate change on river flow regimes has been analysed. Most of them are conducted on a relatively small geographical extent (e.g. on river basin scale) and/or focus on mean annual or seasonal water flow. Only a few large-scale studies were published so far which analysed the impact of climate change on specific flow characteristics or on ecologicallyrelevant flow regimes. Nohara et al. (2006) evaluated the impact of climate change on monthly hydrographs for 24 major rivers in the world. With a focus on extreme events in Europe, changes in flood hazards (Dankers and Feyen, 2009) and hydrological droughts (Feyen and Dankers, 2009) have been analysed for different climate scenarios as well. Döll and Zhang (2010) investigated for the first time the impact of global warming on five ecologically-relevant flow parameters at the global scale and additionally, compared the impacts to flow regime alterations caused by water withdrawals and dam management. The papers of Laizé et al. (2010, 2013) were the first which assessed the combined effects of climate change and socio-economic pressures for different future scenarios, and applied a full set of ecologically-relevant hydrological indicators on a detailed river network covering pan-Europe. Recently, the impact of climate change on ecologically important flood flows has been investigated by Schneider et al. (2011) for floodplain rivers in Europe. This paper aims at evaluating the sole impact of climate change on river flow regimes in Europe, analysing the dynamics separately for each climate zone. In particular the following questions shall be addressed: (i) How will different driving forces such as precipitation, temperature and snowmelt alter in different climate zones? (ii) Where in Europe will flow regime modifications most severe? (iii) How will extreme flow characteristics be impacted in each climate zone? And (iv) what will typical flow regimes look like in the 2050s in the different climate zones?

\section{Methodology}

Assessment of river ecosystem health implies comparison to reference conditions (Norris and Thoms, 1999). In our study, we compare future climate change-impacted flow regimes to natural flow conditions of the present. Thereby, we assume that the more characteristics of the flow regime are relevantly changed, the more severe is the impact on the river ecosystem. Three different model experiments were carried out by the state-of-the-art global hydrology model WaterGAP3 (Verzano, 2009) to assess the impact of climate change on river flow regimes in Europe. Therefore, WaterGAP3 was driven with climate data from three different General Circulation Models (GCMs) to provide 30-yr time series of daily discharge data for the 2050s (2041-2070) and the baseline period (1971-2000), which sets the reference condition. Human impacts such as water withdrawals, return flows, dam management and land-use changes were disabled in WaterGAP3 to focus on the sole effect of climate change. Subsequently, for all simulated time series, general flow statistics were calculated to evaluate the degree of departure from the baseline regimes.

\subsection{Simulation of flow regimes}

For the simulation of river discharge, we applied the latest version of the global water model WaterGAP (i.e. version 3), which has been refined since earlier studies (Alcamo et al., 2003; Döll et al., 2003) and performs its calculations now on a global 5 by 5 arc minutes grid cell raster $\left(\sim 6 \times 9 \mathrm{~km}^{2}\right.$ in Central Europe). The model combines a global hydrology model and a global water use model (Flörke et al., 2012c; Aus der Beek et al., 2010). As our analysis focuses on climate change, only the hydrological component was applied. In order to simulate natural flow conditions, the implemented management of reservoirs and dams was disabled.

The basis of the hydrological component is made up of spatially distributed physiographic characteristics such as land cover, soil properties, topography, permafrost and glaciers, drainage direction, and the location and area of lakes and wetlands. Recently, these datasets have become available as high spatial resolution maps, so that physiographic input parameters and hydrological processes are represented with a higher level of detail (e.g. Farr et al., 2007; Lehner et al., 2008; USGS, 2008). For each individual grid cell, WaterGAP3 calculates daily water balances. The vertical water balance of the land area defines groundwater recharge and surface runoff, taking into account canopy, soil and snow water storages. The water balance of freshwater areas considers lakes and wetlands, and is affected by precipitation and evaporation. To appropriately fill all water storages, a model spin up period of ten years was applied and found to be sufficient. While surface waters started with a full storage for this period, smaller water storages were empty. Both runoff from land and freshwater areas contribute to the total runoff in each grid cell, which is routed along a predefined drainage direction map (DDM5; Lehner et al., 2008) to the next downstream cell. In Europe alone, the simulated river discharge is calibrated at 221 gauging stations against observed annual river flow from the Global Runoff Data Centre (GRDC, 2004). In the calibration process, described in detail by Döll et al. (2003), only one model parameter $(\gamma)$ is adjusted, which affects cell surface runoff generation at gauging stations.

Besides the higher resolution, several hydrological key processes have been improved in WaterGAP3 with special focus on the model's ability to simulate certain flow characteristics: (1) snow-related processes such as snowmeltinduced floods are enhanced by a revised snow routine on a sub-grid scale of 1 arc minute (Verzano and Menzel, 2009); (2) flow velocity is calculated dynamically, allowing for differentiation between mountainous and lowland rivers (Verzano et al., 2012); (3) river length is represented more 
realistically by an individual sinuosity factor per grid cell derived from a high-resolution DDM (Lehner et al., 2008); and (4) permafrost distribution is improved using the Frost Number method (Aus der Beek and Teichert, 2008).

The effect of a changing climate on river flow regimes was taken into account by driving WaterGAP3 with state-of-the art GCM projections for precipitation, air temperature, and long- and shortwave radiation as developed in the WATCH project (Hagemann et al., 2011). For our study, all gridded meteorological forcing data were simply disaggregated to 5 arc minutes to be used in WaterGAP3. In order to consider the uncertainty in current climate modelling, the time series from three different state-of-the art GCMs were applied: (i) ECHAM5/MPI-OM model from the Max-Planck Institute for Meteorology, Germany, (ii) IPSL-CM4 model from the Institute Pierre Simon Laplace, France, and (iii) CNRM-CM3 model from Centre National de Recherches Meteorologiques, France. These GCMs were chosen mainly due to the following reasons: the GCM output was available on a daily time step and covered the whole of Europe. Further, a statistical bias correction was carried out on daily precipitation, minimum, maximum and mean air temperature by means of transfer functions. These functions were used to align the probability distribution function of intensity for these simulated parameters of both historic and future time series (Piani et al., 2010). In comparison to the delta-change approach, which was often used in previous impact studies, this procedure provides more reliable estimates regarding future variability and occurrence of extreme events (Graham et al., 2007). In addition, the WATCH project provided observed climate data for the baseline period (the WATCHforcing data, Weedon et al. 2011), which were applied for the bias-correction of the GCM calculations and could be used for the calibration of the WaterGAP3 model. All three climate projections employed in this study were underpinned by an SRES A2 emission scenario (IPCC, 2007). In the absence of further climate policies, this scenario comprises steadily growing $\mathrm{CO}_{2}$-emissions, which may double by 2050 compared to the year 2000. The SRES A2 scenario was chosen because current $\mathrm{CO}_{2}$ emissions are close to the upper end of the SRES scenario range (Manning et al., 2010). However, due to the inertia of the climate system, the effect of the IPCC emission scenario will become more obvious in the second half of the 20th century (Meehl et al., 2007). Therefore, we decided to focus only on one emission scenario in our study.

\subsection{Indicator assessment}

Trends in different flow characteristics provide an indication as to whether ecologically important habitats are available and life-cycle requirements are met in the future (Suen and Herricks, 2009). In order to assess changes in river flow regimes, we applied a methodology by Laizé et al. (2013), which is based on the Range of Variability Approach (RVA) using Indicators of Hydrological Alteration (IHA; Richter et al., 1996, 1997). The IHA/RVA has been widely used (Yin et al., 2011), is sensitive to anthropogenic influences (Taylor et al., 2004) and recognises that all aspects of the flow regime are ecologically important. It provides 32 different indicators which are organized into five different groups.

Reviewing 171 different hydrologic indicators, Olden and Poff (2003) showed that the IHA capture almost the entire spectrum of all available hydrological indicators, but also duplicate the information for some flow characteristics. Following their framework, a subset of 12 parameters was chosen in our study to describe non-redundant departures from the natural flow regime (Table 1).

In the first step, the 12 parameters were calculated for each year in the 30-yr time series delivering a data record of 30 values per parameter. Second, for each parameter, the 25th, 50th and 75th percentile were calculated from the data record. Third, the final indicators for our study were derived by taking into account the median (i.e. the 50th percentile) as a measure for the average change in magnitude. Additionally, the inter-quartile range (i.e. the difference between the 75 th and the 25th percentile) was determined as a measure for the inter-annual variability in the 30-yr time series (Laizé et al., 2013). Altogether, considering changes in average magnitude and variability, this approach provides 24 different indicators for our impact analysis, which were calculated for the daily time series of all model experiments.

An exception was made in step 2 for the two timing parameters (P23 and P24). Here, the indicators were calculated by specifying the 30 values from the data record as vectors with $x$ - and $y$-coordinates in a unit circle with a radius of one. For this purpose, the 365 days of the year were adjusted to the $360^{\circ}$ (i.e. $2 \pi$ in radians) of the unit circle. Next, the mean $x$ and $y$ components of all vectors were computed, so that the mean timing of the minimum and maximum flow could be calculated by Eq. (1) and the variability $v$ by Eq. (2). In Eq. (1), $\alpha$ describes the angle on the unit circle, which is related to the mean timing. Depending on the quadrant of the mean vector (described by the coordinates $\bar{x}$ and $\bar{y}$ ), $0, \pi$ or $2 \pi$ radians have to be added to $\alpha$.

$$
\begin{aligned}
& \alpha=\tan ^{-1} \frac{\bar{y}}{\bar{x}} \\
& v=1-\sqrt{\bar{x}^{2}+\bar{y}^{2}}
\end{aligned}
$$

For the setting of flow protection standards, attention has recently turned to percent-of-flow (POF) approaches, where the degree of allowable departure is expressed as percentage change to natural conditions (Richter et al., 2012; Yin et al., 2011). In practice, the threshold point at which ecological health is significantly threatened is difficult to determine. Regarding daily flows, Richter et al. (2012) suggest that for most rivers alterations greater than $\pm 20 \%$ will threaten ecological integrity, while river ecosystem with endangered 
Table 1. Hydrologic parameters of the IHA used in this study.

\begin{tabular}{|c|c|c|c|}
\hline ID & Parameter & Unit & Group \\
\hline P1 & January mean flow & $\mathrm{m}^{3} \mathrm{~s}^{-1}$ & Group 1: Magnitude of monthly water conditions \\
\hline $\mathrm{P} 4$ & April mean flow & $\mathrm{m}^{3} \mathrm{~s}^{-1}$ & \\
\hline P7 & July mean flow & $\mathrm{m}^{3} \mathrm{~s}^{-1}$ & \\
\hline $\mathrm{P} 10$ & October mean flow & $\mathrm{m}^{3} \mathrm{~s}^{-1}$ & \\
\hline $\mathrm{P} 13$ & 1-day minimum flow ${ }^{\mathrm{a}}$ & $\mathrm{m}^{3} \mathrm{~s}^{-1}$ & Group 2: Magnitude of extreme water conditions \\
\hline $\mathrm{P} 18$ & 1-day maximum flow ${ }^{\mathrm{b}}$ & $\mathrm{m}^{3} \mathrm{~s}^{-1}$ & \\
\hline $\mathrm{P} 23$ & Julian date of 1-day minimum & Day & Group 3: Timing of extreme water conditions \\
\hline $\mathrm{P} 24$ & Julian date of 1-day maximum & Day & \\
\hline P25 & Number of high pulses ${ }^{c}$ & Number & Group 4: Frequency and duration of high and low pulses \\
\hline $\mathrm{P} 26$ & Number of low pulses ${ }^{\mathrm{d}}$ & Number & \\
\hline P29 & Number of flow rises & Number & Group 5: Rate and frequency of water condition changes \\
\hline P31 & Mean rise rate & $\mathrm{m}^{3} \mathrm{~s}^{-1}$ & \\
\hline
\end{tabular}

a the lowest single daily value occurring during the year; ${ }^{b}$ the highest single daily value occurring during the year; ${ }^{c}$ number of times flow rises above 75 th flow percentile; ${ }^{\mathrm{d}}$ number of times flow drops below 25 th flow percentile.

species or a highly specialized biota require a lower threshold of $10 \%$. For UK rivers, specifying abstraction thresholds as required by the Water Framework Directive, Acreman et al. (2008) defined maximum abstractions to be in the range of 7.5-35\% of natural flow, depending on the ecological sensitivity of the river. Considering threshold values from the literature and the uncertainty of applying a large-scale approach, we assume that the impact on river ecosystems is relevant, when the indicator difference is outside a range of $\pm 30 \%$. An exception was made for the mean timing indicators, where we set the threshold to \pm 30 days.

The whole indicator assessment described above was carried out separately for each WaterGAP3 grid cell of the 5 arc minute European raster, from which a subset of 22915 cells has been selected for our analysis. The criteria of selection was an annual flood of $100 \mathrm{~m}^{3} \mathrm{~s}^{-1}$ or higher to represent major rivers and tributaries in Europe. For ease of display and interpretation of the overall flow regime modification in Sect. 3.2, each grid cell was coloured according to a traffic light coding system (Table 2). As natural flow regimes can be modified in various ways, those indicators showing a threshold exceedance (i.e. the alteration to natural conditions extends $\pm 30 \%$ or 30 days respectively) were summed presuming that each indicator has the same weight.

\subsection{European climate zones}

In order to distinguish the quality of impact in different regions of Europe, an analysis for different climate zones was conducted. The "Map of Climate Areas in Europe" (EUCA15000) divides Europe into 35 different climate areas (Hartwich et al., 2006). For our purposes, the climate areas were aggregated into six classes, namely: polar, boreal, temperate continental, temperate transitional, temperate oceanic and Mediterranean (Fig. 1). WaterGAP's continental grid cells which were not covered by EUCA15000, such as the Near East, were labelled according to the Köppen-Geiger climate classification (Peel et al., 2007). In doing so, arid regions were assigned to the class "Mediterranean".

In general, the six climate zones applied in this study can by described as follows. In the far north of Europe, the polar zone is prevailing. Its climate is characterised by extreme cold winters with often six sub-zero-degree months and cold summers. The boreal climate features very cold winters and short cool summers. Precipitation occurs, with increasing distance to the coast, mainly in the warmer summer months. Soil moisture freezes solidly in winter. The boreal climate is followed by the temperate zone, which was divided into oceanic, transitional and continental climate. In the continental part, the annual variation in climate is high. While summers are hot and dry, winters are very cold. Precipitation is relatively moderate in summer and occurs predominantly during winter. In contrast, temperate oceanic climate provides a narrow annual temperature range as oceans act as a buffer. Summers are warm and winters are mild. Precipitation is high all season and appears in the form of rain most of the year. The transitional zone stands in between and can be described by warm summers, cold winters and all-season precipitation. Areas of the Mediterranean climate zone are mainly located close to the sea, which acts as a temperature buffer. Consequently, the annual temperature range is relatively small. While summers are hot and dry, winters are mild with temperatures generally above the freezing point. Mediterranean areas receive almost all of their annual rain during the winter time. Snow is a rare event, but can occur in high mountain ranges.

\section{Results and discussion}

In the following, the impact of climate change on flow regimes in Europe is evaluated for the 2050s (2041-2070). 


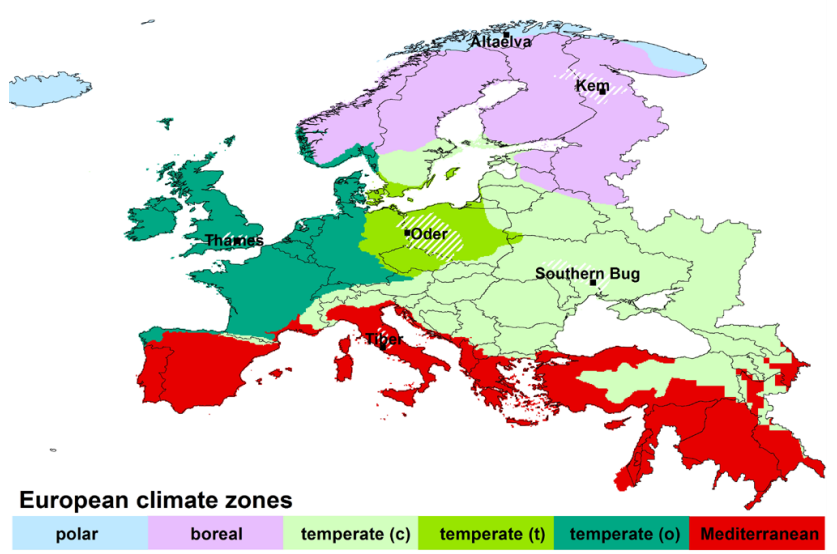

Fig. 1. European climate zones based on information provided by EUCA15000. The six highlighted basins are presented as typical examples in the Results and Discussion chapter.

Table 2. Impact coding system representing the number of indicators which exceed the defined thresholds in the study and their assigned impact on ecology.

\begin{tabular}{lll}
\hline $\begin{array}{l}\text { Threshold } \\
\text { exceedances }\end{array}$ & $\begin{array}{l}\text { Ecological } \\
\text { impact }\end{array}$ & $\begin{array}{l}\text { Colour } \\
\text { code }\end{array}$ \\
\hline $0-5$ & low & green \\
$6-9$ & medium & yellow \\
$10-12$ & high & orange \\
$13-24$ & severe & red \\
\hline
\end{tabular}

First, mean changes in climatic driving forces are presented to differentiate the causes of change in each climate zone. Second, areas in Europe are identified where overall flow regime modification is likely to be most severe. Third, it is shown which of the extreme flow characteristics (i.e. high and low flows) will be considerably modified in the different climate zones and finally, potential future flow regime patterns under climate change are described. In our entire study, we make use of the ensemble mean to mitigate uncertainties in current climate modelling. The ensemble mean was applied on the results of the different indicators, which were calculated for each single model experiment and for each selected grid cell. Changes in future flow regimes for each of the three GCM projections are provided in the Supplement.

\subsection{Change in climatic driving forces}

Hydrological flow regimes will be modified by climate change in the future through alterations in precipitation, temperature and snow cover (Fig. 2).

A north-south divide can be found for precipitation in $\mathrm{Eu}$ rope. In general, the north is getting wetter and the already dry south is receiving even less precipitation. In the winter half-year (i.e. October to March), only the Mediterranean

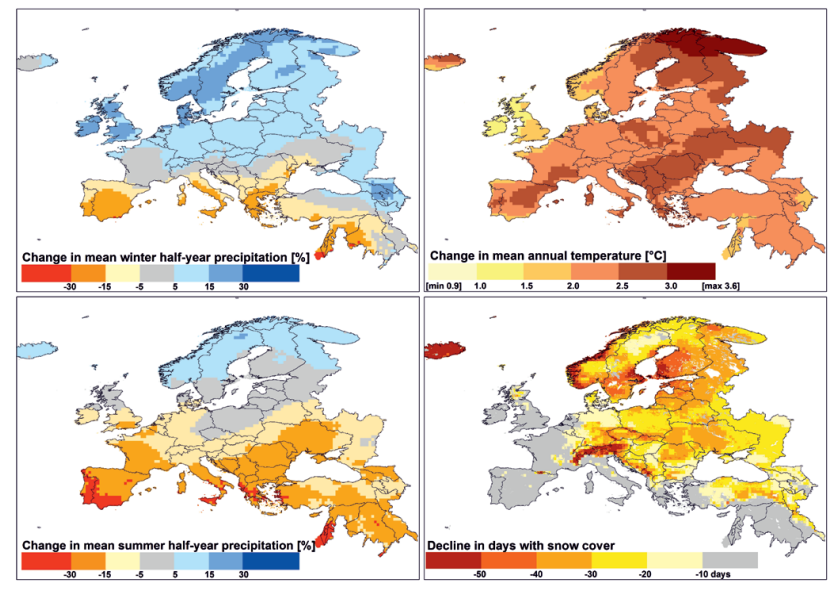

Fig. 2. Climatic changes in the 2050s featuring changes from the baseline in mean precipitation of winter and summer half-year (left), mean annual temperature and snow cover duration (right). The maps represent the ensemble mean of the three climate projections.

countries receive less precipitation, while the remaining part of Europe and in particular the north faces higher amounts of precipitation. In the summer half-year (i.e. April to September), reduction in precipitation is getting more severe in the Mediterranean countries, and Eastern Europe is also highly affected. Temperature is supposed to increase in all parts of Europe, but especially in the far north and in Eastern Europe. As a consequence, evapotranspiration rates are likely to be higher leading to a reduction in runoff (Frederick and Major, 1997). Furthermore, the duration of snow cover decreases with strongest impacts for the Baltic Sea rim countries, but also in mountainous regions (Alps, Dinaric Alps, the Carpathians, Rila Mountains, Icelandic and Scandinavian Mountains). Vanham (2012) concludes in his review that climate change projections indicate substantial reductions in future snow cover duration for the Alps. On the west coast of Europe, temperature rise is more moderate. The average values of change for each climate zone are presented in Table 3. Regarding the uncertainty range for the mean values, the climate projections of the three GCMs coincide in the direction of change in almost all climate zones. Only in the polar zone, one climate projection points in the opposite direction for winter precipitation.

\subsection{Overall flow regime modification}

According to the simulated changes in the different climate variables, climate change has the potential to modify flow regimes remarkably across Europe in the 2050s. Döll and Zhang (2010) even concluded in their work that climate change is likely to have a stronger and more widespread impact on flow regime modification than water abstractions and dam operation have had up to now. In our study, severe impacts can be found in Southern Europe, which is likely to 
Table 3. Mean change in climate variables for the different climate zones of Europe derived from the ensemble mean. The brackets contain the range of the three climate projections.

\begin{tabular}{llll}
\hline Climate zone & $\begin{array}{l}\text { Precipitation } \\
\text { winter }[\%]\end{array}$ & $\begin{array}{l}\text { Precipitation } \\
\text { summer }[\%]\end{array}$ & $\begin{array}{l}\text { Temperature } \\
\text { annual }\left[{ }^{\circ} \mathrm{C}\right]\end{array}$ \\
\hline Polar & $+8.7(-2.9$ to +15.6$)$ & $+8.8(+6.7$ to +10.2$)$ & $+2.7(1.7$ to 3.7$)$ \\
Boreal & $+13.8(+3.6$ to +22.4$)$ & $+6.0(+4.0$ to +7.7$)$ & $+2.6(1.8$ to 3.7$)$ \\
Temperate continental & $+3.5(+1.2$ to +8.1$)$ & $-13.4(-16.9$ to -11.7$)$ & $+2.4(1.9$ to 2.8$)$ \\
Temperate transitional & $+10.2(+1.9$ to +20.2$)$ & $-2.4(-3.2$ to -1.4$)$ & $+2.4(1.8$ to 2.9$)$ \\
Temperate oceanic & $+8.8(+1.9$ to +15.1$)$ & $-9.9(-14.6$ to -6.4$)$ & $+2.0(1.6$ to 2.2$)$ \\
Mediterranean & $-11.9(-19.3$ to -6.9$)$ & $-23.0(-29.3$ to -19.0$)$ & $+2.3(2.1$ to 2.4$)$ \\
\hline
\end{tabular}

suffer under reduced precipitation in both summer and winter half-year, and in Scandinavia, where precipitation amounts increase throughout the year and the decline in snow cover plays a crucial role (Fig. 3). Furthermore, mountainous regions such as the Carpathians and Balkan mountains are hotspots for flow regime modifications. Here, considerable reductions in snowmelt and summer precipitation are indicated for the 2050s. In Western Europe (i.e. in the UK, Ireland, BENELUX, Denmark, Galicia and France) the impact is lowest. Hydrological alterations caused by changes in precipitation and temperature are more moderate in these regions and the impact of snow is low. Our results are in accordance to the study of Laizé et al. (2013), who analysed the impact on environmental flows under different future scenarios with monthly flow indicators and found strongest impacts for the Mediterranean and the southwest part of Eastern Europe. However, with our setup (i.e. different climate change projections with bias-correction and daily flow indicators) the impacts for Northern Europe were stronger.

Regarding the impact in different climate zones, the extent of flow regime modification varies (Fig. 4). According to our results, the highest degree of river flow regime alteration can be expected in the Mediterranean and in the boreal climate zone. Here, respectively $28 \%$ and $23 \%$ of the analysed grid cells are affected by severe climate change impacts and the number of grid cells with a low impact is marginal. In the temperate climate zone, impacts increase from west to east. In the oceanic part, $86 \%$ of the cells still remain in the low and medium impact class in the 2050s, in the continental part only $37 \%$. The temperate transitional climate zone possesses $66 \%$ in these two classes. Allan et al. (2005) stated that the location of a river basin relative to the ocean may dampen its response to climate change. For our analysis of total flow regime modification, results for individual flow characteristics were added together and the same threshold was applied for all flow characteristics. It has to be considered that a relatively small change in low flows can produce a large percentage change, with the opposite result for high flows. Hence, more research on individual thresholds is required for the different flow characteristics.

\subsection{Modification of extreme flow statistics}

Besides the degree of flow regime modification, it is also important to consider which flow characteristics are modified in the future as they determine which ecological functions are compromised and thus, which species of flora and fauna are likely to become vulnerable. Climate change impacts on high flow magnitudes (P18) and timing (P24) are shown for the 2050s in Fig. 5. Maximum flow magnitudes are likely to be higher in Sweden, Norway and in the UK due to projected increases in winter precipitation. Maximum flows relevantly decrease in Southern Europe (Spain, Middle and South Italy, Greece, and at rivers influenced by the Taurus Mountains in Turkey) due to the strong decreases in precipitation throughout the year, as well as in Eastern Europe (especially at Rivers influenced by the Carpathians and the Balkan mountains). As a consequence, floodplains in Eastern Europe could be less inundated under climate change with negative effects on floodplain vegetation and fish (Schneider et al., 2011). The timing of flood peaks will be shifted more often towards earlier month as found by Döll and Zhang (2010). In our study, earlier flood peaks are likely to occur in the eastern part of Europe and partly, where rivers originated at high mountains (e.g. Carpathians and Taurus mountains). These changes in high flows can be explained by rising temperatures which cause the $0^{\circ} \mathrm{C}$ level to be crossed earlier in the year. In addition, precipitation more often falls as rain instead of snow. Therefore, thaw happens earlier and less water is stored as snow pack leading to advanced and lower snowmelt-induced flood peaks in Eastern Europe.

In Europe, low flows usually occur in late-summer or early-autumn. Due to the decline in mean summer precipitation over large parts of Europe and increasing evapotranspiration rates, further reductions in low flows (P13) can be expected in southern and eastern regions. Only in Scandinavia can elevated low flows be observed (Fig. 6). For both low and high flow magnitudes, no relevant changes were detected for the UK, Ireland, Denmark, the BENELUX, the Baltic states, and for most rivers in Germany.

As climate variables are variously affected in the diverse climate zones, different flow characteristics will be modified (Fig. 7). Minimum flow magnitudes (P13) are strongly 


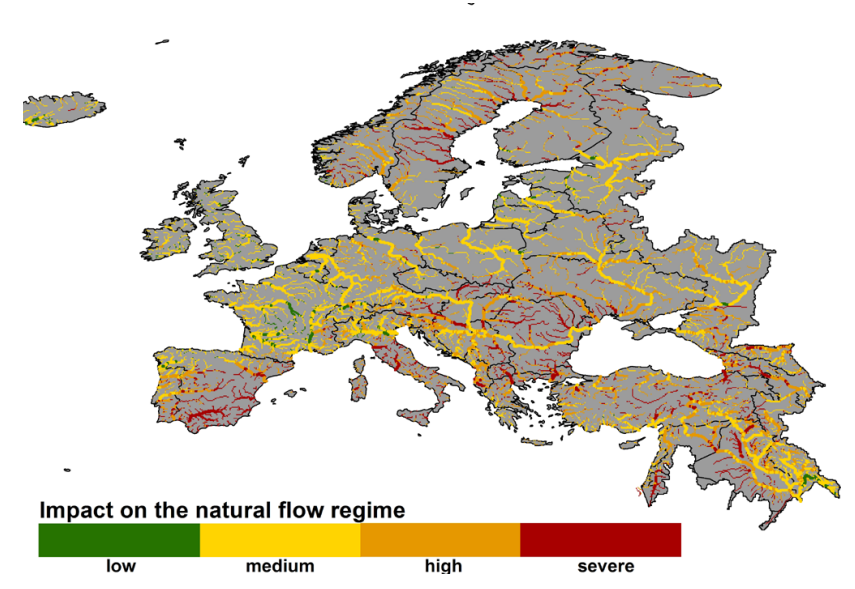

Fig. 3. Climate change impact on the natural flow regime in the 2050s under the A2 emission scenario considering 24 selected indicators and the ensemble mean of the three climate projections.

impacted in the Mediterranean (decrease) and the Northern climates (increase) followed by the temperate continental climate zones where summers get notably drier. On the contrary, low flows are only marginally impacted in the temperate transitional and oceanic zone. Maximum flow magnitudes (P18) are again most intensively modified in the Mediterranean climate zone, but also in the boreal climate zone. While the timing of minimum flows (P23) will be strongly modified in the two Northern climates, timing of maximum flows (P24) is mainly altered in the snow climates with warmer summers. In both cases (i.e. for high and low flows), especially the boreal climate zone is likely to be impaired by a shift in timing.

\subsection{Flow regimes in the 2050s in different climate zones}

In this section, we present for each climate zone, how "typical" monthly flow regimes may look like in the 2050s under the exclusive effect of climate change. The results may be valid for most rivers in each climate zone, but local variants are possible due to local effects such as high mountain ranges, the storage of water in lakes and wetlands, glacier melt water augmentation, ice jam or anthropogenic modifications. In order to show how homogeneous the results are for each climate zone, the percentage change of monthly discharge is presented by means of Whisker-boxplots which depict the median, the 25th and 75th percentile of all selected grid cells belonging to a climate zone. The ends of the whiskers indicate the minimum and maximum value of the sample, excluding outliers. In addition, the effects on the flow regime within a climate zone are explained by a hydrograph of a representative river. These example rivers were chosen by reason of their central location within the climate zone and their character to reflect the climate-zone-specific flow regime changes as illustrated by the Whisker-boxplots. The related hydrographs contain the ensemble mean of both

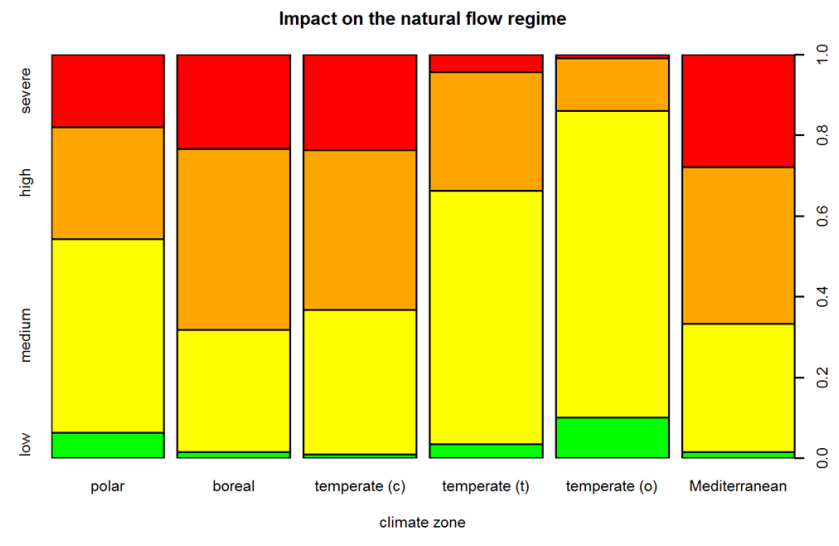

Fig. 4. Impact of climate change on natural flow regimes for different climate zones in the 2050 s, represented by the proportion of grid cells showing low, medium, high or severe impact.

the monthly natural flow regime of the baseline period and the flow regime of the 2050s under climate change. For the latter one, the uncertainty range caused by the three GCM projections is included.

\subsubsection{Polar zone}

Owing to the long and extreme cold winter in the polar zone, thaw happens very late in spring, causing a massive flood peak centred usually in May or June. After extreme low flows in winter, this flood delivers more than 60 per cent of the total annual flow within three months (Haines et al., 1988). According to the climate projections, the polar zone faces the highest temperature rise (i.e. $+2.7^{\circ} \mathrm{C}$ on average) and an increase in mean precipitation in both summer and winter half year. In our study, flows tend to be higher in most months of the year and the higher evapotranspiration rates are outweighed by higher precipitation amounts (Fig. 8).

Particularly in April, depending on the location of the site, the flow increase can be very high as thaw proceeds faster and starts earlier in the year due to the higher temperatures. Snowmelt-induced flood peaks in May and June show different directions of change with slightly more than $50 \%$ of the sites indicating lower discharges. A closer analysis indicated that lower flood peaks are likely to occur mainly in Iceland. On the contrary, peak flows tend to increase in Northern Scandinavia due to the considerably higher projected winter precipitation, which causes more snow to be stored in the snow pack, leading to higher snowmelt-induced flood peaks. The example of the Altaelva River in Northern Norway describes a typical example for the continental part of the polar zone. Here, peak flows are higher compared to the natural flow regime, but decline faster as a result of the accelerated thaw, which can lead to lower flows in early summer despite an increase in rainfall. 

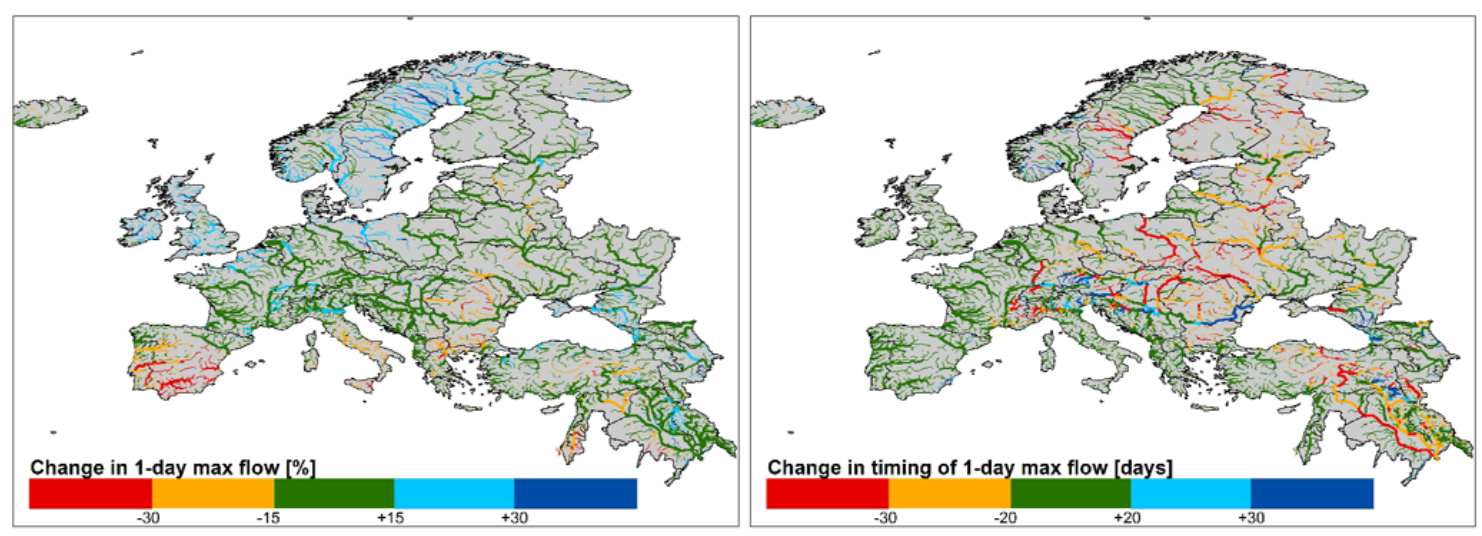

Fig. 5. Change of high flow magnitude and timing as a result of climate change represented by the ensemble mean for the 2050 s.

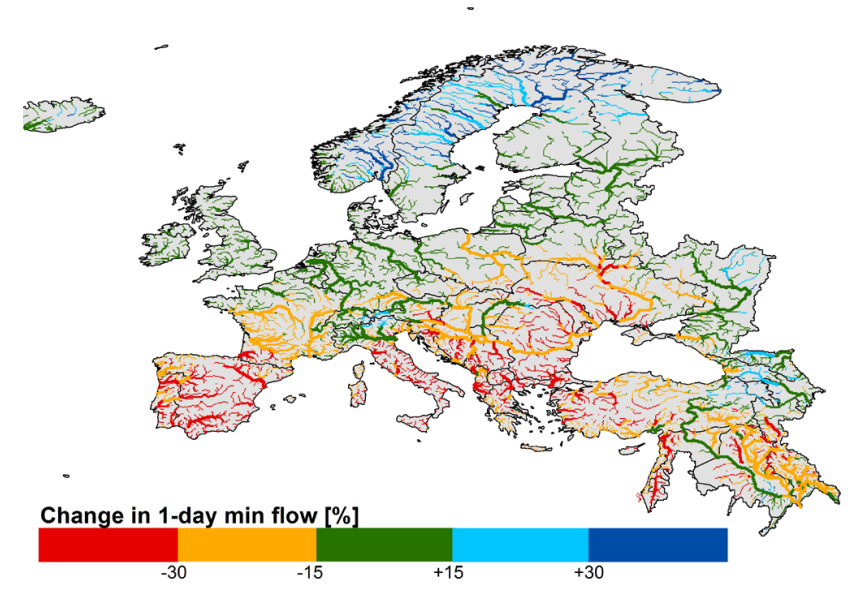

Fig. 6. Change in low flow magnitude caused by climate change represented by the ensemble mean for the 2050 s.

\subsubsection{Boreal zone}

In the boreal zone as well, only little solar energy input is received during the winter time so that snow can accumulate for five to six month, often without interruption by melt events. Again, the prevalent flow pattern is the nival regime where snowmelt and ice break-up cause winter low flows to be rapidly displaced by a spring freshet, which usually peaks in May (Woo et al., 2008). In summer, flows recede due to higher evapotranspiration, but a minor secondary peak can occur in mid-autumn with emerging rainstorms at this time (Haines et al., 1988). In the European boreal zone, the highest mean winter precipitation increases are projected for the 2050 s (i.e. $+13.8 \%$ ), but also mean summer precipitation is expected to rise by $6 \%$. Accordingly, future winter discharges are higher compared to the natural flow regime, while summer flows are less impacted (Fig. 9).

In the boreal region, the advanced thaw is most distinct in comparison to other climate zones (see Fig. 2). Consequently, the highest impact can be found on flows in April

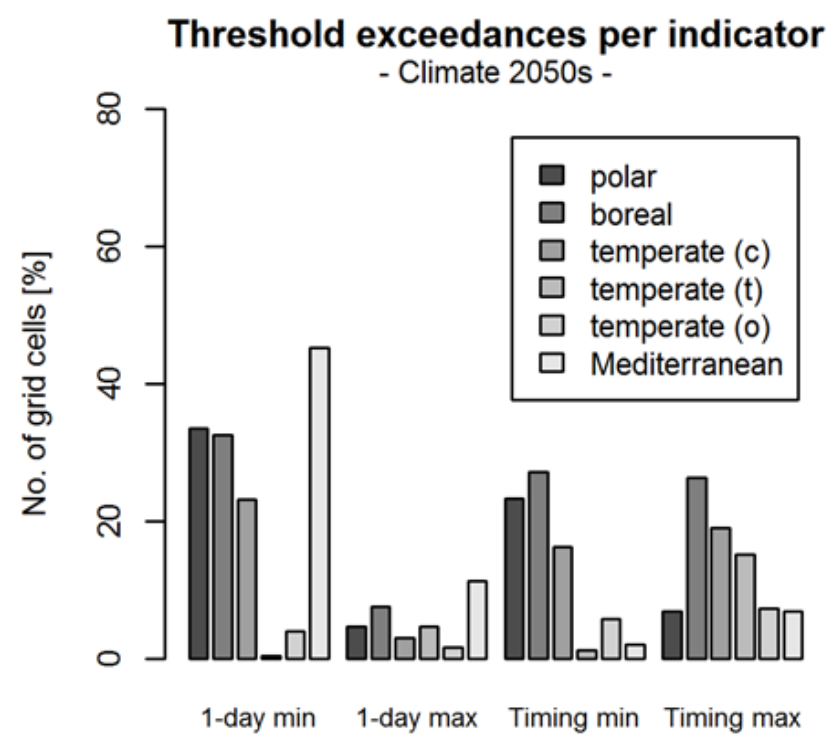

Fig. 7. Percentage of grid cells which are relevantly affected by climate change according to climate zones in Europe. Magnitude and timing of low and high flows are distinguished.

as discharge peaks, instead of May, one month earlier in the future. The earlier timing of snowmelt in spring and sporadic melt events in the winter months reduce the snow storage. However, in Sweden and Norway, these effects are more than compensated in our study by higher precipitation values and here, spring freshet magnitudes are more likely to increase in the 2050s. Winter flows are elevated in the boreal climate zone due to the increased precipitation, rainfall (instead of snow) and occasional melt events occurring already in the winter months in the 2050s. During summer (June to September), increased precipitation is often outweighed by a higher evapotranspiration rate. In our study, around half of the grid cells tend to a lower discharge in summer. The hydrograph of the Chirko-Kem River in Karelia (Russia) gives a typical example for the boreal zone with 

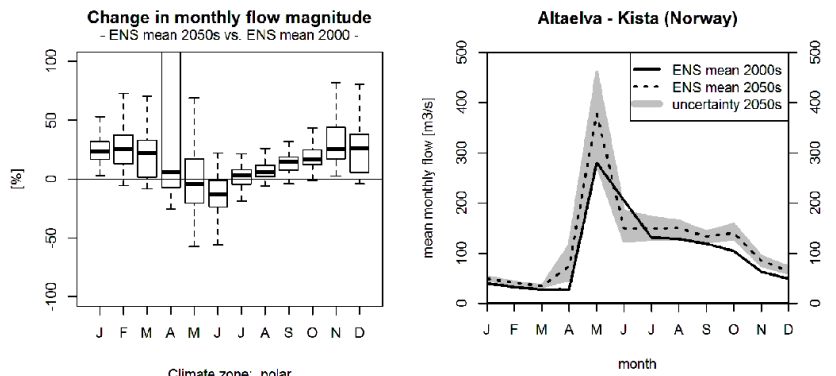

Climate zone: polar

Fig. 8. Direction of change in the 2050s plotted for all grid cells of the polar climate zone (left) and the Altaelva river near Kista (right).

an advanced snowmelt-induced flood peak. Different studies analysing stream flow trends in Scandinavia (Bergstrom and Carlsson, 1993), European Russia (Georgiyevsky et al., 1995, 1996, 1997), and the Baltic States (Tarend, 1998) indicate that winter, summer and autumn flows are increasing, but spring flows have been decreasing since the mid-1970s. Such results were also found by Woo et al. (2008), who analysed stream flow hydrology in the boreal region on the global scale.

In addition to the climate change impacts, many rivers are already heavily regulated by dams in the boreal region, predominantly for the purpose of hydroelectric power generation. However, Renöfält et al. (2010) see opportunities under climate change for both a more sustainable production of hydroelectricity and the restoration of river ecosystems. Usually, electricity demand is high in winter where river flows are at a minimum level. Under climate change, especially winter flows are expected to increase and the annual surplus of water in this region could be used to operate dams in a way which makes flow regimes more natural again.

\subsubsection{Temperate continental zone}

According to the Haines et al. (1988) classification, rivers in the temperate continental zone peak in early or mid-spring. At this time, spring floods could be produced by rainfall alone, but usually these events are enhanced by the release of winter precipitation, which was stored as snow during the colder month. In the summertime, flows typically decline until they rise again in late autumn. The ensemble mean of the precipitation projections indicates that in the 2050s the high variability in the continental climate zone will be augmented (see Fig. 2). While precipitation slightly increases in winter, the drier summers will be intensified receiving $13.4 \%$ less precipitation, which accounts for the second highest reduction after the Mediterranean climate zone. Furthermore, mean temperature increase (i.e. $+2.4{ }^{\circ} \mathrm{C}$ ) will be higher than in the temperate oceanic climate zone. The WaterGAP3 simulations in this climate zone show that winter flows increase, but peak flows in spring as well as summer and autumn flows are likely to be lower in the 2050s (Fig. 10).
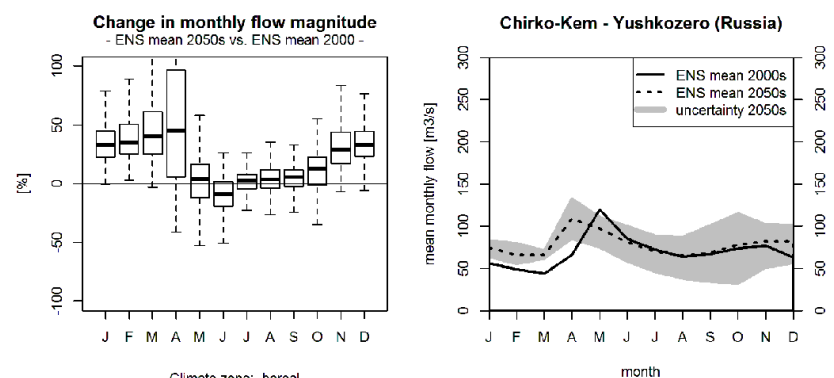

Fig. 9. Direction of change in the 2050s plotted for all grid cells of the boreal climate zone (left) and the Chirko-Kem river near Yushkozero (right).

Due to the reduced summer precipitation, flows tend to be remarkably lower between April and November. Thaw peaks are reduced and occur earlier in the year due to the discussed changes in snowmelt, which will have a high impact in this region with very cold winter months. However, the earlier timing is often less advanced than 30 days. The example of the Southern Bug River shows that both maximum and minimum flows are reduced. Regarding the boxplots which represent the entire region, the widest ranges of change were found in comparison to other climate zones. The reason is that the continental climate zone is the biggest area in our study containing important mountain ranges such as Alps, Pyreneans and Carpathians and ranging from south Sweden to Turkey, causing local extremes or divergencies. However, the direction of change is very homogeneous over the region from April to September. Winter flows (December to February) tend to be increased in the 2050s, but show a wider range of change. For the Black Sea region, Flörke et al. (2012b) found that cross-sectoral conflicts may arise in the future due to increasing water withdrawals for irrigation and electricity production purposes. In addition to the climate change impact, this would further reduce flows in the summer, intensifying the impact on the river flow regimes in this region.

\subsubsection{Temperate transitional zone}

Flow regime patterns in the temperate transitional zone are quite similar to flow regimes in the continental part of Europe, but more uniform. High flows ascend slower and earlier in spring. Low flows are less distinct. The simulated climate conditions for this region project a relatively high mean temperature increase by $2.4^{\circ} \mathrm{C}$ until the 2050s. No explicit change in summer precipitation is detected in all three climate projections, but mean winter precipitation is expected to increase by $10.2 \%$ in the ensemble mean. Our simulated hydrographs in this region show only a strong impact in the three winter months of the 2050s (Fig. 11), exemplarily depicted at the Oder river.

Relatively consistent for the entire region, the results indicate slightly lower flows between April and November due to 

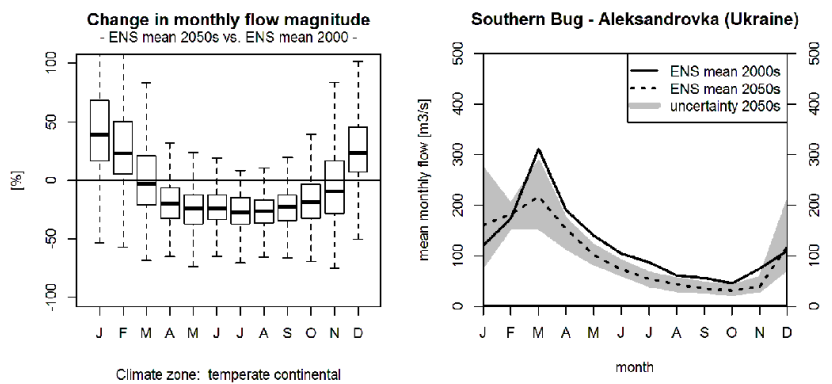

Fig. 10. Direction of change in the 2050s plotted for all grid cells of the temperate continental climate zone (left) and the Southern Bug river near Aleksandrova (right).

higher temperatures and slightly reduced precipitation. Peak flows usually occurring in March or April are rarely modified but can be slightly advanced. Nevertheless, in the future, the transitional temperate climate zone could be a region, where discharge formation will not be substantially influenced anymore by snowmelt. The projected increase in winter precipitation, transition of snowfall to rain, and so-called "rain on snow events" can cause that rainfall triggers immediate runoff peaks, making winter flows not only higher, but also more variable in this region. Such a trend from snowmelt runoff regimes to winter rainy regimes has already been observed at some locations (Allan et al., 2005).

\subsubsection{Temperate oceanic zone}

In the moist temperate oceanic zone with fairly even precipitation throughout the year, flow regimes are more uniform. Usually, they possess a broad winter peak (in Scotland, a broad autumn peak) and lower flows in summer due to evapotranspiration losses (Haines et al., 1988). The lowest value for temperature rise (i.e. $+2.0^{\circ} \mathrm{C}$ on average) was found for this region adjoining the Atlantic coast. However, mean winter precipitation is increasing by $8.8 \%$ and mean summer precipitation is decreasing by $9.9 \%$ over the whole region in the ensemble mean.

In response to the more moderate changes in climate variables, river flow regimes of the 2050s are less affected by climate change (Fig. 12). Nevertheless, flows in the summer half-year tend to be reduced in the 2050s and flows in the winter months (December to February) show an increase. The example hydrograph of the Thames river near Teddington illustrates almost natural flow conditions in the future, which could be maintained in the temperate oceanic zone and especially in the UK. Trend analyses of river flow regimes in the UK show no clear climate-driven statistical trends so far for both high (Robson et al., 1998) and low flows (Hisdal et al., 2001). In Ireland and Scotland, in the last forty years increasing runoff values were discovered by Hannaford et al. (2007).
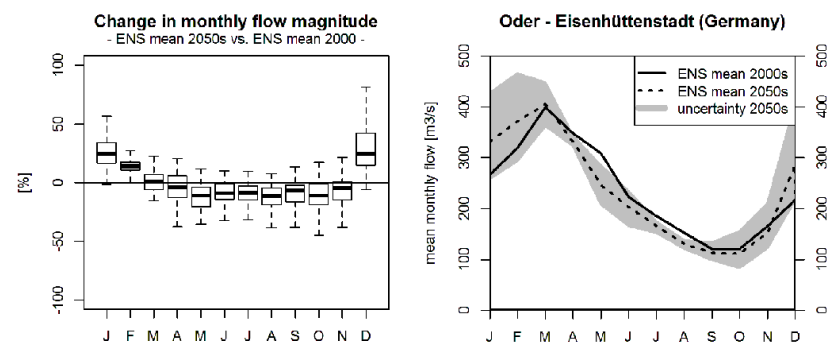

Climate zone: temperate trans itional

month

Fig. 11. Direction of change in the 2050s plotted for all grid cells of the temperate transitional climate zone (left) and the Oder river near Eisenhüttenstadt (right).
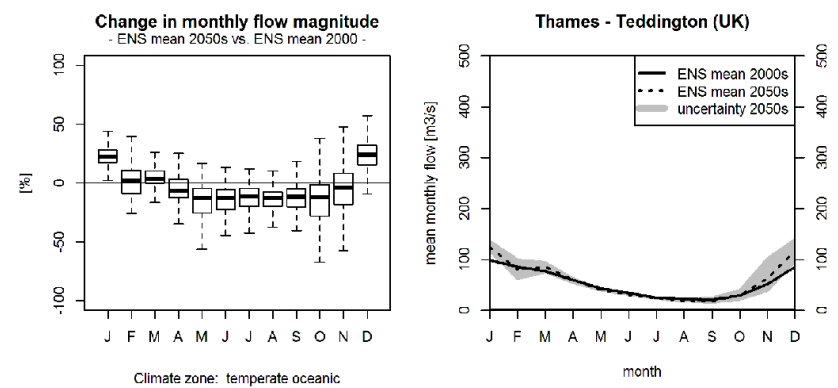

Fig. 12. Direction of change in the 2050s plotted for all grid cells of the temperate oceanic climate zone (left) and the Thames river near Teddington (right).

\subsubsection{Mediterranean zone}

River flow regimes in the Mediterranean climate zone are highly variable (Oueslati et al., 2010). While precipitation mainly occurs in the winter half-year, extensive low or even zero flow patterns can appear during the dry summer months, which can lead to isolated pools along the river (Argyroudi et al., 2009) and transitions from lotic to lentic waters (Morais et al., 2004). Hydrological simulations for the Mediterranean climate zone are characterised by a strong reduction in mean precipitation in both winter and summer half-year. Especially in summer, precipitation decreases by $23 \%$ which accounts for the highest decline found in our study. While Nohara et al. (2006) concluded in his work that discharge tends to decrease at Mediterranean rivers of Europe, our flow regime simulations for the 2050s indicate that river discharge is likely to be lower during the entire year (Fig. 13).

While changes in river flow show very consistent results for the whole region between April and September, the range of change is very broad from October to March. One reason for this is the impact of different mountains ranges in Southern Europe (e.g. Turkish mountains elevate up to $3900 \mathrm{~m}$ ), so that runoff can be influenced at some locations by snow. The hydrograph of the Tiber river near Rome shows that flow reduction is severe throughout the year. However, the broad variety of uncertainty in winter river discharge (January to 

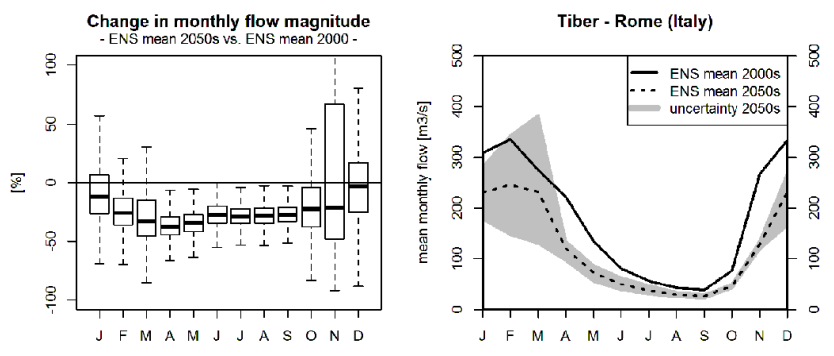

Climate zone: Mediterranean

Fig. 13. Direction of change in the 2050s plotted for all grid cells of the Mediterranean climate zone (left) and the Tiber river near Rome (right).

March) is remarkable and indicates the different GCM calculation of future precipitation. According to the WaterGAP3 simulations, river flows in the Mediterranean are likely to be even more intermittent in the future, with an increasing number of zero flow events creating isolated pools. Moreover, in a holistic context, this situation caused by climate change will be exacerbated as large amounts of water are withdrawn in this region for irrigation purposes (Schaldach et al., 2012). Additionally, water quality will be negatively affected as the concentration of pollutants increases when flows are reduced. Consequently, especially here, intelligent dam management according to the Block Building Methodology (BBM; Tharme and King, 1998) or the Basic Flow Methodology (BFM; Palau and Alcazar, 2012) will be required to provide at least certain flow elements that are ecologically important.

\section{Conclusions}

This study aimed at evaluating the future impact of climate change on river flow regimes in Europe and identifying the dynamics separately for each climate zone. Therefore, natural flow regimes of the present-day and future climate change impacted flow regimes of the 2050s were modelled by the global hydrology model WaterGAP3 taking into account bias-corrected climate projections of three different GCMs. Subsequently, alterations in various flow characteristics were assessed applying the Indicators of Hydrological Alteration.

Our results show that besides other anthropogenic factors, climate change may severely alter natural patterns of flow over large regional scales. Regarding the total degree of flow regime modification, strongest impacts on European river flow regimes in the 2050s were found for the Mediterranean and the boreal climate zone. The smallest impacts, in turn, can be expected for the temperate oceanic climate zone. However, a west-east gradient became obvious in the temperate zone, with increasing impacts from oceanic towards

the continental part of the temperate climate with highest impacts around the Carpathians and the Balkan mountains.

Changes in temperature, precipitation and snowmelt interact differently at different climate zones, causing diverse flow characteristics to be altered. In the boreal climate zone, WaterGAP3 calculations indicated that snow cover duration is considerably reduced. In accordance with that, the timing of both high and low flows, was predominantly modified in our simulations in the boreal region of Europe.

In the continental part of the polar zone as well as in the Norwegian and Swedish part of the boreal climate zone, flood peaks tend to be increased due to remarkably higher projected winter precipitation and faster proceeding snowmelt in spring. On the contrary, in the temperate continental climate zone, high flows leading to ecologically important floodplain inundation are likely to be reduced. Due to rising temperatures, the impact of thaw is debased, leading to lower snowmelt-induced flood peaks in spring.

In most regions, climate change constitutes a threat additional to other anthropogenic factors, in particular in the dry Mediterranean climate zone, where flows are likely to be lower in all months of the year in the 2050s, exacerbating the impacts of high water abstraction for irrigation purposes in this region. But also in the continental climate zone, where high amounts of water are withdrawn for electricity production and irrigation, climate change is likely to further reduce river flows remarkably from spring until autumn. Summer precipitation is expected to decrease over large parts in $\mathrm{Eu}-$ rope, but especially in Southern and Eastern Europe.

At least in the boreal zone, climate change could provide opportunities to re-establish a more natural flow regime. Many rivers are modified in Scandinavia by dam operations to support hydropower demands, but competition between different water use sectors is marginal. As precipitation is expected to increase in both winter and summer half-year, the surplus of water could be used to operate dams in a way which benefits river ecosystems.

The consequences of flow regime change are manifold. Related water quantity and water quality issues can provoke socio-economic and environmental problems. Especially river ecosystem health and provision of ecosystem services are threatened as further modifications of natural flow patterns will make species more vulnerable to extinction. Freshwater ecosystems might somehow adapt to the new conditions and probably find a new equilibrium. However, we want to emphasize that, in reference to ecological impact analyses quoted in this study, this will presumably be accompanied by a loss in biodiversity, at which especially endangered and specialised species could become extinct, or be replaced by invasive species. At some point, thresholds could be crossed with unforeseeable consequences for mankind (Jenkins, 2003). Our results show that the need for environmental flow actions is further increasing under climate change, and various effects of climate change need to be considered. To reduce further stress on river ecosystems, 
adaptive environmental flow management, intelligent dam operation providing ecologically important elements of the flow regime (e.g. by the Block Building Methodology), and provision of high flows for floodplain wetland inundation are required.

\section{Supplementary material related to this article is available online at: http://www.hydrol-earth-syst-sci.net/ 17/325/2013/hess-17-325-2013-supplement.pdf.}

Acknowledgements. The financial support from the EU's Research Framework Programme (FP6) under contract no. GOCE 036822 (SCENES) and 036946 (WATCH) is gratefully acknowledged. The first author is thankful for the possibility of doing research at the Centre for Ecology and Hydrology in Wallingford, UK.

Edited by: J. Liu

\section{References}

Acreman, M. C., Dunbar, M. J., Hannaford, J., Wood, P. J., Holmes, N. J., Cowx, I., Noble, R., Mountford, J. O. D., King, J., Black, A., Extence, C., Crookall, D., and Aldrick, J.: Developing environmental standards for abstractions from UK rivers to implement the Water Framework Directive, Hydrolog. Sci. J., 53, 1105-1120, 2008.

Alcamo, J., Döll, P., Henrichs, T., Kaspar, F., Lehner, B., Rösch, T., and Siebert, S.: Development and testing of the WaterGAP 2 global model of water use and availability, Hydrolog. Sci. J., 48, 317-337, 2003

Alcamo, J., Flörke, M., and Märker, M.: Future long-term changes in global water resources driven by socio-economic and climate changes, Hydrolog. Sci. J., 52, 247-275, 2007.

Allan, J. D., Palmer, M. A., and Poff, N. L.: Climate change and freshwater ecosystems, in: Climate Change and Biodiversity, Yale University Press, New Haven CT, 272-290, 2005.

Argyroudi, A., Chatzinikolaou, Y., Poirazidis, K., and Lazaridou, M.: Do intermittent and ephermal Mediterranean rivers belong to the same river type?, Aquat. Ecol., 43, 465-476, 2009.

Arnell, N. W.: Climate change and global water resources: SRES emissions and socio-economic scenarios, Global Environ. Change, 14, 31-52, 2004.

Arnell, N. W., van Vuuren, D. P., and Isaac, M.: The implications of climate policy for the impacts of climate change on global water resources, Global Environ. Change, 21, 592-603, 2011.

aus der Beek, T. and Teichert, E.: Global Permafrost Distribution in the Past, Present and Future, Proc., 9th International Conference on Permafrost, Fairbanks, Alaska, 29 June-3 July 2008.

aus der Beek, T., Flörke, M., Lapola, D. M., Schaldach, R., Voß, F., and Teichert, E.: Modelling historical and current irrigation water demand on the continental scale: Europe, Adv. Geosci., 27, 79-85, doi:10.5194/adgeo-27-79-2010, 2010.

Bergstrom, S. and Carlsson, B.: Hydrology of the Baltic Basin, Swedish Meteorological and Hydrological Institute Reports, Hydrology, 7, 1-21, 1993.
Brown, J. H. and Lomolino, M. V.: Biogeography (Second Edition), Sinauer, Sunderland, USA, 1998.

Bunn, S. E. and Arthington, A. H.: Basic Principles and Ecological Consequences of Altered Flow Regimes for Aquatic Biodiversity, Springer-Verlag New York Inc., 30, 492-507, doi:10.1007/s00267-002-2737-0, 2002.

Costanza, R., d'Arge, R., de Groot, R., Faber, S., Grasso, M., Hannon, B., Limburg, K., Naeem, S., O’Neill, R. V., Paruelo, J., Raskin, R. G., Sutton, P., and van der Belt, M.: The value of the world's ecosystems and natural capital, Nature, 387, 253-260, 1997.

Dankers, R. and Feyen, L.: Flood hazard in Europe in an ensemble of regional climate scenarios, J. Geophys. Res.-Atmos., 114, D16108, doi:10.1029/2008JD011523, 2009.

Döll, P. and Zhang, J.: Impact of climate change on freshwater ecosystems: a global-scale analysis of ecologically relevant river flow alterations, Hydrol. Earth Syst. Sci., 14, 783-799, doi:10.5194/hess-14-783-2010, 2010.

Döll, P., Kaspar, F., and Lehner, B.: A global hydrological model for deriving water availability indicators: model tuning and validation, J. Hydrol., 270, 105-134, 2003.

Farr, T. G., Rosen, P. A., Caro, E., Crippen, R., Duren, R., Hensley, S., Kobrick, M., Paller, M., Rodriguez, E., Roth, L., Seal, D., Shaffer, S., Shimada, J., Umland, J., Werner, M., Oskin, M., Burbank, D., and Alsdorf, D.: The Shuttle Radar Topography Mission, Rev. Geophys., 45, RG2004, doi:10.1029/2005RG000183, 2007.

Feyen, L. and Dankers, R.: Impact of global warming on streamflow drought in Europe, J. Geophys. Res.-Atmos., 114, D17116, doi:10.1029/2008JD011438, 2009.

Flörke, M., Bärlund, I., and Kynast, E.: Will climate change affect the electricity production sector? A European study, Water Clim. Chang., 3, 44-54, doi:10.2166/wcc.2012.066, 2012a.

Flörke, M., Bärlund, I., Schneider, C., and Kynast, E.: PanEuropean freshwater resources in a changing environment: how will the Black Sea region develop?, Water Sci. Technol., 12.5, 563-572, 2012b.

Flörke, M., Kynast, E., Bärlund, I., Eisner, S., Wimmer, F., and Alcamo, J.: Domestic and industrial water uses of the past 60 years as a mirror of socio-economic development: A global simulation study, Global Environ. Chang., online first: doi:10.1016/j.gloenvcha.2012.10.018, 2012c.

Frederick, K. D. and Major, D. C.: Climate change and water resources, Climatic Change, 37, 7-23, 1997.

Georgiyevsky, V. Y., Zhuravin, S. A., and Ezhov, A. V.: Assessment of trends in hydrometeorological situation on the Great Russian Plain under the effect of climate variations, in: Proceedings of American Geophysical Union, 15th Annual Hydrology Days, 47-58, 1995.

Georgiyevsky, V. Y., Yezhov, A. V., Shalygin, A. L., Shiklomanov, A. I., and Shiklomanov, I. A.: Evaluation of possible climate change impact on hydrological regime and water resources of the former USSR rivers, Russ. Meteorol. Hydrol., 11, 89-99, 1996.

Georgiyevsky, V. Y., Yezhov, A. V., and Shalygin, A. L.: An assessment of changing river runoff due to man's impact and global climate warming, in: River Runoff Calculations, Report at the International Symposium, UNESCO, 75-81, 1997.

Giller, P. S. and Malmqvist, B.: The Biology of Streams and Rivers, Oxford, UK, Oxford University Press, 1998. 
Graham, L. P., Hagemann, S., Jaun, S., and Beniston, M.: On interpreting hydrological change from regional climate models, Climatic Change, 81, 97-122, 2007.

GRDC: Long Term Mean Monthly Discharges and Annual Characteristics of Selected GRDC Stations, the Global Runoff Data Centre: Koblenz, Germany, 2004.

Grooten, M., Almond, R., and McLellan, R.: Living Planet Report 2012: biodiversity, biocapacity and better choices (WWF), available at: http://wwf.panda.org/about_our_earth/all_publications/ living_planet_report/ (last access: 27 June 2012), 2012.

Hagemann, S., Chen, C., Haerter, J. O., Heinke, J., Gerten, D., and Piani, C.: Impact of a statistical bias correction on the projected hydrological changes obtained from three GCMs and two hydrology models, J. Hydrometeorol., 12, 556-578, doi:10.1175/2011JHM1336.1, 2011.

Haines, A. T., Finlayson, B. L., and McMahon, T. A.: A global classification of river regimes, Appl. Geogr., 8, 255-272, 1988.

Hannaford, J., Laizé, C. L. R., and Marsh, T. J.: An assessment of runoff trends in natural catchments in the Celtic regions of North West Europe, in: Proceedings of the Fourth InterCeltic Colloquium on Hydrology and Management of Water Resources, Guimaraes, Portugal, 11-14 July 2005, IAHS Red Book, Wallingford, Oxfordshire, UK, 310, 78-85, 2007.

Hartwich, R., Thiele, S., Baritz, R., Fuchs, M., and Krug, D.: Erläuterungen zur Bodenregionenkarte der Europäischen Union und ihrer Nachbarstaaten im Maßstab $1: 5.000 .000$ Version 2.0), the report additionally contains the Map of Climate Areas in Europe $1: 15,000,000$, and the Parent Material Associations Map $1: 15,000,000$. Both maps, together with the EU soil regions map, are part of the BGR digital soil data catalogue, available at: http://www.bgr.bund.de (last access: 20 January 2013), BGR, Hannover, 2006.

Hisdal, H., Stahl, K., Tallaksen, L. M., and Demuth, S.: Have streamflow droughts in Europe become more severe or frequent?, Int. J. Climatol, 21, 317-333, doi:10.1002/joc.619, 2001.

IPCC: Climate Change 2007: Synthesis Report. Contribution of Working Groups I, II and III to the Fourth Assessment Report of the Intergovernmental Panel on Climate Change, edited by: Pachauri, R. K. and Reisinger, A., IPCC, Geneva, Switzerland, 104 pp., 2007.

Jenkins, M.: Prospects for biodiversity, Science, 302, 1175-1177, 2003

Laizé, C. L. R., Acreman, M. C., Dunbar, M. J., Houghton-Carr, H., Flörke, M., and Schneider, C.: Monthly hydrological indicators to assess impact of change on river ecosystems at the pan-European scale: preliminary results, in: British Hydrological Society Third International Symposium Role of Hydrology in Managing Consequences of a Changing Global Environment, Newcastle upon Tyne, UK, 2010.

Laizé, C. L. R., Acreman, M. C., Schneider, C., Dunbar, M. J., Houghton-Carr, H., Flörke, M., and Hannah, D. M.: Projected flow alteration and ecological risk for pan-European rivers, River Res. Appl., online first, doi:10.1002/rra.2645, 2013.

Lehner, B., Verdin, K., and Jarvis, A.: New global hydrography derived from spaceborne elevation data, Eos T. Am. Geophys. Un., 89, 93-94, 2008.

Lloyd, N., Quinn, G., Thoms, M., Arthington, A., Gawne, B., Humphries, P., and Walker, K.: Does flow modification cause geomorphological and ecological response in rivers?, A literature review from an Australian perspective, Technical report 1/2004, CRCFE, Canberra, 2004

Lytle, D. A. and Poff, N. L.: Adaptation to natural flow regimes, Trends Ecol. Evol., 19, 94-100, doi:10.1016/j.tree.2003.10.002, 2004.

Malmqvist, B. and Rundle, S.: Threats to the running water ecosystem of the world, Environ. Conserv., 29, 134-153, doi:10.1017/S0376892902000097, 2002.

Manning, M. R., Edmonds, J., Emori, S., Grubler, A., Hibbard, K. Joos, F., Kainuma, M., Keeling, R. F., Kram, T., Manning, A. C., Meinshausen, M., Moss, R., Nakicenovic, N., Riahi, K., Rose, S. K., Smith, S., Swart, R., and van Vuuren, D. P.: Misrepresentation of the IPCC $\mathrm{CO}_{2}$ emission scenarios, Nat. Geosci., 3, 376-377, 2010.

Mathews, R. and Richter B.: Application of the Indicators of Hydrologic Alteration software in environmental flow-setting, J. Am. Water Resour. As., 43, 1400-1413, doi:10.1111/j.17521688.2007.00099.x, 2007

Meehl, G. A., Stocker, T. F., Collins, W. D., Friedlingstein, P., Gaye, A. T., Gregory, J. M., Kitoh, A., Knutti, R., Murphy, J. M., Noda, A., Raper, S. C. B., Watterson, I. G., Weaver, A. J., and Zhao, Z. C.: Global climate projections. Climate Change 2007: The Physical Science Basis. Contribution of Working Group I to the Fourth Assessment Report of the Intergovernmental Panel on Climate Change, edited by: Solomon, S., Qin, D., Manning, M., Chen, Z., Marquis, M., Averyt, K. B., Tignor, M., and Miller, H. L., Cambridge University Press, Cambridge, 747-846, 2007.

Milly, P. C. D., Betancourt, J., Falkenmark, M., Hirsch, R. M., Kundzewicz, Z. W., Lettenmaier, D. P., and Stouffer, R. J.: Stationarity Is Dead: Whither Water Management?, Science, 319, 573-574, doi:10.1126/science.1151915, 2008.

Morais, M., Pinto, P., Guilherme, P., Rosado, J., and Antunes, I.: Assessment of temporary streams: the robustness of metric and multimetric indices under different hydrological conditions, Hydrobiologia, 516, 229-249, 2004.

Nilsson, C. and Renöfält, B. M.: Linking flow regime and water quality in rivers: a challenge to adaptive catchment management, Ecol. Soc., 13, available at: http://www.ecologyandsociety.org/ articles/2588.html (last access: August 2012), 2008

Nilsson, C., Reidy, C. A., Dynesius, M., and Revenga, C.: Fragmentation and Flow Regulation of the World's Large River Systems, Science, 308, 405-408, 2005.

Nohara, D., Kitoh, A., Hosaka, M., and Oki, T.: Impact of Climate Change on River Discharge Projected by Multimodel Ensemble, J. Hydrometeorol., 7, 1076-1089, 2006.

Norris, R. H. and Thoms, M. C.: What is river health?, Freshwater Biol., 41, 197-209, 1999.

Olden, J. D. and Poff, N. L.: Redundancy and the choice of hydrologic indices for characterizing streamflow regimes, River Res. Appl., 19, 101-121, doi:10.1002/rra.700, 2003.

Oueslati, O., De Girolamo, A. M., Abouabdillah, A., and Lo Porto, A.: Attempts to flow regime classification and characterisation in mediterranean streams using multi-variate analysis, Int. Workshop Advances in Statistical Hydrology, Taormina, Italy, 2325 May 2010, 1-15, 2010.

Palau, A. and Alcázar, J.: The basic flow method for incorporating flow variability in environmental flows, River Res. Appl., 28, 93 102,2012 
Peel, M. C., Finlayson, B. L., and McMahon, T. A.: Updated world map of the Köppen-Geiger climate classification, Hydrol. Earth Syst. Sci., 11, 1633-1644, doi:10.5194/hess-11-16332007, 2007.

Piani, C., Weedon, G. P., Best, M., Gomes, S. M., Viterbo, P., Hagemann, S., and Haerter, J. O.: Statistical bias correction of global simulated daily precipitation and temperature for the application of hydrological models, J. Hydrol., 395, 199-215, 2010.

Poff, N. L. and Zimmerman, J. K. H.: Ecological responses to altered flow regimes: a literature review to inform the science and management of environmental flows, Freshwater Biol., 55, 194205, doi:10.1111/j.1365-2427.2009.02272.x, 2010.

Poff, N. L., Allan, J. D., Bain, M. B., Karr, J. R., Presteegard, K. L., Richter, B. D., Sparks, R. E., and Stromberg, G. J. C.: The natural flow regime, BioScience, 47, 769-784, 1997.

Renöfält, B. M., Jansson, R., and Nilsson C.: Effects of hydropower generation and opportunities for environmental flow management in Swedish riverine ecosystems, Freshwater Biol., 55, 4967, doi:10.1111/j.1365-2427.2009.02241.x, 2010.

Ricciardi, A. and Rasmussen, J. B.: Extinction rates of North American freshwater fauna, Conserv. Biol., 13, 1220-1222, 1999.

Richter, B. D.: Re-thinking environmental flows: from allocations and reserves to sustainability boundaries, River Res. Appl., 26, 1052-1063, doi:10.1002/rra.1320, 2009.

Richter, B. D., Baumgartner, J. V., Powell, J., and Braun, D. P.: A Method for Assessing Hydrologic Alteration within Ecosystems, Conserv. Biol., 10, 1163-1174, 1996.

Richter, B. D., Baumgartner, J. V.,Wigington, R., and Braun, D. P.: How much water does a river need?, Freshwater Biol., 37, 231249, 1997.

Richter, B. D., Davis, M. M., Apse, C., and Konrad, C.: A presumptive standard for environmental flow protection, River Res. Appl., 28, 1312-1321, doi:10.1002/rra.1511, 2012.

Robson, A. J., Jones, T. K., Reed, D. W., and Bayliss, A. C.: A study of national trend and variation in UK floods, Int. J. Climatol., 18, 165-182, 1998.

Rost, S., Gerten, D., Bondeau, A., Luncht, W., Rohwer, J., and Schaphoff, S.: Agricultural green and blue water consumption and its influence on the global water system, Water Resour. Res., 44, 1-17, doi:10.1029/2007WR006331, 2008.

Sahin, V. and Hall, M. J.: The effects of afforestation and deforestation on water yields, J. Hydrol., 178, 293-309, 1996.

Schaldach, R., Koch, J., Aus der Beek, T., Kynast, E., and Flörke, M.: Current and future irrigation water requirements in panEurope: An integrated analysis of socio-economic and climate scenarios, Global Planet. Change, 94-95, 33-45, 2012.

Schneider, C., Flörke, M., Geerling, G., Duel, H., Grygoruk, M., and Okruszko, T.: The future of European floodplain wetlands under a changing climate, J. Water Clim. Change, 2, 106-122, 2011.

Strayer, D. J. and Dudgeon, D.: Freshwater biodiversity conservation: recent progress and future challenges, J. N. Am. Benthol Soc., 29, 344-358, 2010.

Suen, J. P. and Herricks, E. E.:Developing fish community based ecohydrological indicators for water resources management in Taiwan, Hydrobiologia, 625, 223-234, doi:10.1007/s10750-0099710-3, 2009.
Tarend, D. D.: Changing flow regimes in the Baltic States, in: Proceedings of the 2nd International Conference on Climate and Water, Espoo, Finland, August 1998, 109-117, 1998.

Taylor, V., Jewitt, G. P. W., and Schulze, R. E.: Indicators of Hydrologic Alteration for assessing environmental flows for highly variable rivers, Report commissioned by the Water Research Commission, 1155/1/04, 121-137, 2004.

Tharme, R. E. and King, J. M.: Development of the Building Block Methodology for instream flow assessments, and supporting research on the effects of different magnitude flows on riverine ecosystems, Water Research Commission Report No. 576/1/98, 452 pp., 1998.

USGS: Global Land Cover Characterization (GLCC), available at: http://edc2.usgs.gov/glcc/glcc.php (last access: 27 June 2012), 2008.

Vanham, D.: The Alps under climate change: implications for water management in Europe, J. Water Clim. Change, 3, 197-206, doi:10.2166/wcc.2012.032, 2012.

Verzano, K.: Climate change impacts on flood related hydrological processes: Further development and application of a global scale hydrological model, Reports on Earth System Science, 71-2009, Max Planck Institute for Meteorology, Hamburg, Germany, 2009.

Verzano, K. and Menzel, L.: Snow conditions in mountains and climate change - a global view, in: Hydrology in Mountain Regions: Observations, Processes and Dynamics, IAHSPublication, Wallingford, Oxfordshire, UK, 326, 147-154, 2009.

Verzano, K., Bärlund, I., Flörke, M., Lehner, B., Kynast, E., and Voß, F.: Modeling variable river flow velocity on continental scale: Current situation and climate change impacts in Europe, J. Hydrol., 424-425, 238-251, 2012.

Vörösmarty, C. J., McIntyre, P. B., Gessner, M. O., Dudgeon, D., Prusevich, A., Green, P., Glidden, S., Bunn, S. E., Sullivan, C. A., Reidy Liermann, C., and Davies, P. M.: Global threats to human water security and river biodiversity, Nature, 467, 555-561, doi:10.1038/nature09440, 2010.

Weedon, G. P., Gomes, S., Viterbo, P., Shuttleworth, W. J., Blyth, E., Österle, H., Adam, J. C., Bellouin, N., Boucher, O., and Best, M.: Creation of the WATCH Forcing Data and its use to assess global and regional reference crop evapotranspiration over land during the twentieth century, J. Hydrometeorol., 12, 823-848, doi:10.1175/2011JHM1369.1, 2011.

Woo, M. K., Thorne, R., Szeto, K. K., and Yang, D.: Streamflow hydrology in the boreal region under the influences of climate and human interference, Philos. T. R. Soc. Lond., B, 363, 22512260, doi:10.1098/rstb.2007.2197, 2008.

Yin, X. A., Yang, Z. F., and Petts, G. E.: Reservoir operating rules to sustain environmental flows in regulated rivers, Water Resour. Res., 47, 1-13, doi:10.1029/2010WR009991, 2011.

Zang, C. F., Liu, J., van der Velde, M., and Kraxner, F.: Assessment of spatial and temporal patterns of green and blue water flows under natural conditions in inland river basins in Northwest China, Hydrol. Earth Syst. Sci., 16, 2859-2870, doi:10.5194/hess-162859-2012, 2012. 